\title{
Classic in a modern interpretation: on oil flax (Linum Usitatissimum L.) in the middle preduralie
}

\author{
Yu.N. Zubarev*, and Yu.A. Sosnin \\ Perm SATU, Petropavlovskaya St., 23, 614900 Perm, Russia
}

\begin{abstract}
The article is considered the problem of oil flax (Linum usitatissimum L.) cultivation on sod-podzolic soils of the Middle Preduralie, devoted to the relevance and importance of studying the agricultural methods of oil flax cultivation in the agro-climatic conditions of the Middle Preduralie. Economic viability of flax crop cultivation for oilseeds and practical applicability of seed processing products is presented. The methods of field experiment carried out on research and experimental field of the Department of General Agriculture and Plant Protection based at the Faculty of Agricultural Technologies and Forestry, the Perm SATU, are described. The results of two-year research show the influence of pre-sowing tillage and herbicide treatment of oil flax on the yield capacity of oilseeds in the Middle Preduralie. Tendencies are noted and some analytical theses are derived.
\end{abstract}

\section{Introduction}

At present, practical science is more and more interested in the introduction of new crops and development of high agro-technologies for them. Perennial burnet polygamous (Poterium polygamum), Jerusalem artichoke (Helianthus tuberosus), maral root (Rhaponticum carthamoides), etc. came to attention of practical science. In this regard, history of oil flax cultivation in the Ural region and the Middle Preduralie receives special attention. Oil flax is unpretentious crop in terms of cultivation conditions. Following the minimum technological and agrochemical requirements, it is produced both in the southern and northern regions in many countries of the world [1]. Modern varieties of oil flax have a stable yield, respond well to soil fertility, are drought-resistant, technologically advanced and reliable. Unlike quite complex harvesting and processing technologies of fiber flax cultivation that requires special-purpose machines, oil flax requires a simple cultivation technology and a set of agricultural machines used for the majority of cereal crops.

According to Rosstat's data, the average level of real incomes of citizens, in comparison with the indicators of five years ago, has fallen by almost $10 \%$, while the debt owed only on mortgage loans for the same period increased by more than 2 times [2]. Stable development and functioning of agriculture as a source of food and food products assumes particular importance in these turbulent circumstances. In this regard, oil flax is a subject of

\footnotetext{
* Corresponding author: yn-zubarev@mail.ru
} 
consideration and detailed examination. Different in intensity technologies of oil flax cultivation allows achieving seed yield in the range of 1-3 $\mathrm{t} / \mathrm{ha}$, which provides a profitability of up to $90 \%$ at a cost price of 12-17 thousand rubles per ton.

Flax sown area in world agriculture is equal to 2.5-3 million ha with an average productivity of $1.01 \mathrm{t} / \mathrm{ha}$. Oil flax remains the most important agricultural crop of general and multi-purpose use (oil, flax-fiber, forage linseed cake and meal, technical raw materials for paint and varnish industry, soap manufacture, leather and footwear industry, etc.) [3]. It is not by chance that oil flax is cultivated in 50 foreign countries but the main producers of oil flax seeds («The Flaxen Six») are Canada, Russia, Kazakhstan, China, the USA, India.

Significant land resources and agro-climatic potential with seasonal moisture inflow of $700-800 \mathrm{~mm}$ in the Middle Preduralie favor the formation of highly productive flax sowings for food and animal husbandry fodder, where it is possible to use cake and meal obtained from linseed oil processing.

\subsection{Relevance}

Practical calculations of efficiency show that profitability of oil flax cultivation is ensured at the level of $20 \%$ even at the low yield capacity of seeds $(0.6 \mathrm{t} / \mathrm{ha})$. At the yield capacity of $1 \mathrm{t} / \mathrm{ha}$, profitability measures up to $100 \%$ and it is equal to $120-135 \%$ at the seed yield of more than $1-1.5 \mathrm{t} / \mathrm{ha}$.

The simplicity of agricultural technology, ecological crop plasticity, low cost of expenditures on oil flax cultivation as well as situation on the global and regional markets of the crop allowed Russia in the 2010s from an outsider in the oil flax production to become one of the leading seed-producing countries. High demand on products obtained from flax arose not least due to its beneficial qualities [4]. Flax seed oil contains polyunsaturated fatty acids such as Docosahexaenoic, Eicosapentaenoic, and alphaLinolenic acids [5] characterized by their medical properties. Research data regarding the correlation of diet supplements contained flax seed oil with the positive dynamics of health indicators: control of glucose level in type 2 diabetes patients [6], optimization of lipid profile [7] is available.

It is known that in the Perm Krai once cultivated sowings of fiber flax reduced from 43 thousand ha in 1956 to an actually critical level -4 thousand ha in 1991. Production and intensive investigation of this crop was completely stopped. No information is found regarding oil flax in the Ural region.

In 2019, field research of oil flax with the «Uralskii» variety was started in the Perm State Agro-Technological University on the base of the Department of General Agriculture and Plant Protection. The topic of research was «The influence of pre-sowing tillage and herbicide treatment of oil flax on the yield capacity of oilseeds in the Middle Preduralie».

2019 presented a number of natural anomalies in the Perm Krai, first of all, this concerned precipitation regime. Thus, $937 \mathrm{~mm}$ of precipitation fell in 2019, $387 \mathrm{~mm}$ of which was for the period of field experiment realization (May-September 2019).

Excessive moisture worked for the benefit, since oil flax is a moisture-loving crop. According to the Flax Experimental Station of the Moscow Timiryazev Agricultural Academy, oil flax can absorb about 7 tons of moisture for $16 \mathrm{~kg}$ of yield (oilseeds) during the vegetative period.

\subsection{Working Hypothesis}

Oil flax in agro-climatic conditions of the Middle Preduralie at the optimal method of presowing soil tillage is expected to form yield of at least $1 \mathrm{t} / \mathrm{ha}$, when herbicide treatment preserves crops from weed plants. 


\section{Methods and Materials}

\subsection{Location, object, and experimental procedure}

In 2019-2020, two establishments of field experiment of oil flax, the «Uralskii» variety, were carried out at the Department of General Agriculture and Plant Protection of the Perm State Agro-Technological University.

Two-factor field experiment «The influence of pre-sowing tillage and herbicide treatment oil flax on the yield capacity of oilseeds in the Middle Preduralie» was conducted according to the following experimental design [8]:

Factor A - herbicide treatment, where:

- A0 - without herbicide treatment (control)

- A1 - single treatment in a stem extension phase

- double treatment in a stem extension phase and once more after 3-5 weeks

The «Lontrel-300» herbicide was chosen for the research as an optimally compatible with flax crop. An average recommended dose was applied: $200 \mathrm{ml}$ of herbicide by 1001 of water by 1 ha.

Factor B - pre-sowing soil tillage, where:

- $\mathrm{B} 1$ - one-row harrowing (control)

- $\quad$ B2 - chisel tillage with one-row harrowing

- B3 - chisel tillage with two-row harrowing

- $\mathrm{B} 4-$ one-row disk tillage

- $\mathrm{B} 5$ - one-row roto-tillage

- B6 - one-row tillage with the AKP-1.6 «Lider» unit

Design of the field experiment is represented on the Fig. 1

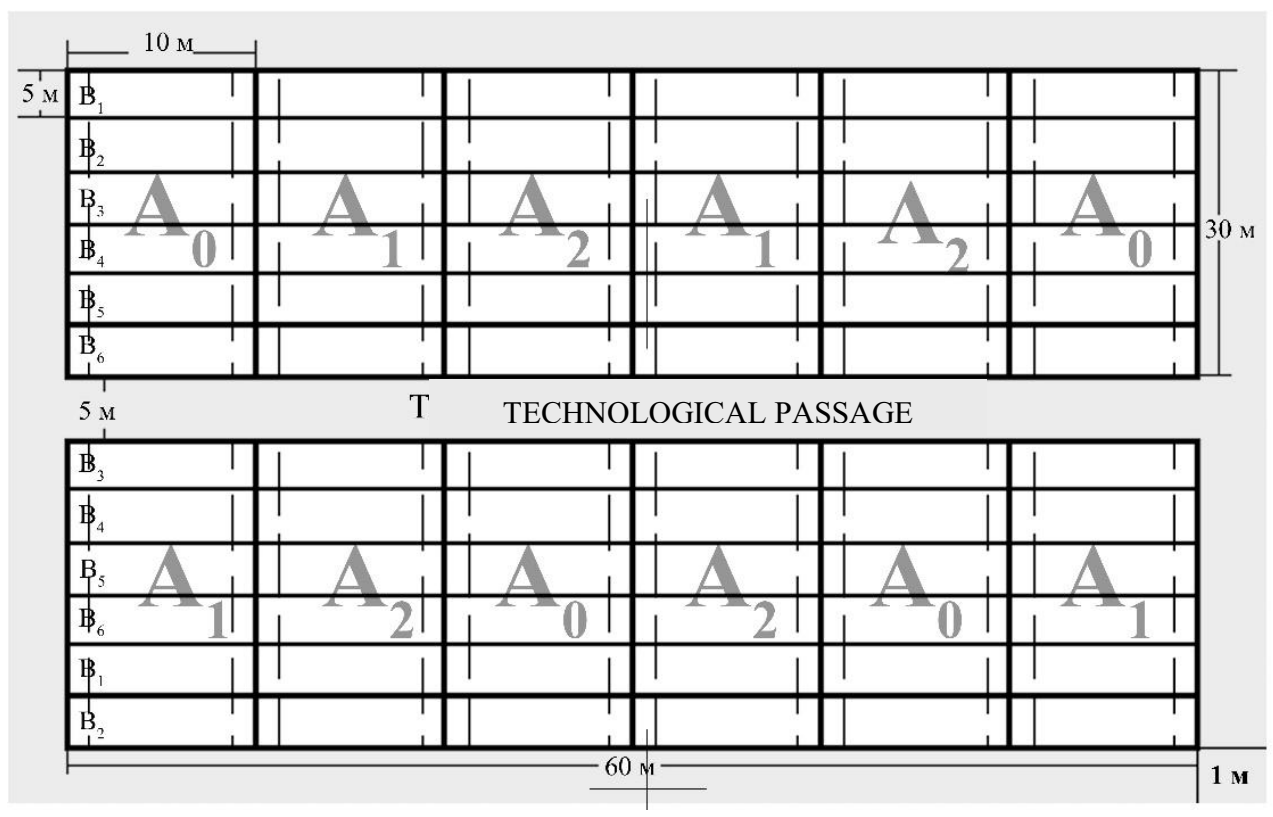

Fig. 1. Design of the field experiment «The influence of pre-seeding tillage and herbicide treatment of oil flax on the yield capacity of oilseeds in the Middle Preduralie» 


\subsection{Agricultural methods and tools}

Early-spring harrowing with the BZST-1 tooth harrow was previously applied on physically mature soil to a depth of 4-6 cm on experimental field used for research.

Pre-sowing soil tillage was carried out with the following units: the BZST-1 tooth harrow, the KPS-4 cultivator in a unit with harrows, the BDM-4 disk harrow, the FN-0.7 direct-connected rotary plow, the «Lider» AKP-1.8 combined unit. Sowing of seeds was conducted in prescribing rates with the use of the SPU-3 pneumatic multi-purpose seeding machine. The 3-KKSH-6 ribbed-ball rollers were used for seed rolling after sowing [9].

Herbicide treatment was implemented with the ONSH-600 sprayer unit.

\subsection{Agrochemicals and Materials}

Fertilizers were implemented in an average recommended dose N45P60K30 before soil treatment [10].

Experimental sowings were carried out straight after soil treatment according to an average recommended rate -10 million units per ha (or $60 \mathrm{~kg} / \mathrm{ha}$ at a rate of specified mass equal to 1000 seeds $-6 \mathrm{~g}$ ) [11].

Sowings were treated with the «Lontrel-300» herbicide in a dose of $200 \mathrm{ml}$ of herbicide by 1001 of water by 1 ha of treated area.

\section{Results and Discussion}

The yield of oil flax seeds of the «Uralskii» variety was obtained during the field experiment. The control variant of experiment (method of pre-sowing soil tillage - one-row harrowing without herbicide treatment) provided the yield capacity equal to $1.06 \mathrm{t} / \mathrm{ha}$. Double treatment with the «Lontrel-300» herbicide contributed to a qualitative reduce in amount of weeds, which in turn insured the yield capacity by $10.2 \%$ higher $-1.18 \mathrm{t} / \mathrm{ha}$. The highest yield capacity was obtained on B4 variants with the method of pre-sowing disk tillage regardless of herbicide treatment. Double treatment contributed to yield formation of $1.38 \mathrm{t} / \mathrm{ha}$, which is by $30 \%$ higher than the control variant without herbicide treatment. Final average yield is represented in the Table 1.

Table 1. The influence of pre-sowing tillage and herbicide treatment of oil flax on the yield capacity of oilseeds, $\mathrm{t} / \mathrm{ha}$

\begin{tabular}{|c|c|c|c|}
\hline \multirow{2}{*}{$\begin{array}{c}\text { Method of pre-seeding } \\
\text { soil tillage (Factor B) }\end{array}$} & $\begin{array}{c}\text { Without treatment } \\
\text { (A0) } \\
\text { (control) }\end{array}$ & $\begin{array}{c}\text { Single treatment in a stem } \\
\text { extension phase } \\
\text { (A1) }\end{array}$ & $\begin{array}{c}\text { Double treatment in a stem } \\
\text { extension phase and when } \\
\text { weeds grow (A2) }\end{array}$ \\
\hline $\begin{array}{c}\text { harrowing (B1) } \\
\text { (контроль) }\end{array}$ & 1.06 & 1.08 & 1.18 \\
\hline $\begin{array}{c}\text { chisel tillage with one-row } \\
\text { harrowing } \\
\text { (B2) }\end{array}$ & 1.19 & 1.21 & 1.21 \\
\hline $\begin{array}{c}\text { chisel tillage with two-row } \\
\text { harrowing (B3) }\end{array}$ & 1.10 & 1.22 & 1.24 \\
\hline one-row disk tillage (B4) & 1.19 & 1.32 & 1.38 \\
\hline one-row roto-tillage (B5) & 1.09 & 1.28 & 1.36 \\
\hline $\begin{array}{c}\text { mixed cultivation in one- } \\
\text { row (B6) }\end{array}$ & 0.93 & 1.16 & 1.32 \\
\hline
\end{tabular}

Treatment with the «Lontrel-300» herbicide of oil flax sowings contributed to the yield formation. Thus, the number of weeds in the control variants without herbicide treatment 
(in average, 213 pcs per $\mathrm{m}^{2}$ ) prior to harvesting was by $44 \%$ higher than the number of weeds in the variants with single treatment (in average, 148 pcs per $\mathrm{m}^{2}$ ). It was almost by $128 \%$ higher than the variants with double herbicide treatment during vegetative period (in average, 96 pcs per $\mathrm{m}^{2}$ ). The average number of weeds according to the variants of experiment is represented in the Table 2 in dependence of herbicide treatment.

Table 2. The influence of herbicide treatment of oil flax sowings on the number of weeds, pcs per $\mathrm{m}^{2}$

\begin{tabular}{|c|c|c|c|c|}
\hline \multirow{2}{*}{$\begin{array}{c}\text { Herbicide treatment } \\
\text { (Factor A) }\end{array}$} & \multicolumn{4}{|c|}{ The average number of weeds } \\
\cline { 2 - 5 } & $\mathrm{pcs} / \mathrm{m}^{2}$ & $\%$ & $\mathrm{pcs} / \mathrm{m}^{2}$ & $\%$ \\
\hline $\begin{array}{c}\text { Without treatment } \\
\text { (A0) }\end{array}$ & 12 & 100 & 213 & 100 \\
\hline $\begin{array}{c}\text { Single treatment in a } \\
\text { stem extension phase } \\
\text { (A1) }\end{array}$ & 17 & 141.7 & 148 & 69.5 \\
\hline $\begin{array}{c}\text { Double treatment in a } \\
\text { stem extension phase } \\
\text { and when weeds grow } \\
\text { (A2) }\end{array}$ & 11 & 91.7 & 96 & 45.07 \\
\hline
\end{tabular}

\section{Conclusion}

The following tendencies were specified in analysis of data:

1) Pre-sowing soil tillage with the BDM-4 disk harrow (Factor B4) regardless herbicide application contributed to the yield formation in average by $22 \%$ higher than control tillage with harrow (Factor B1).

2) Double treatment of sowings with herbicide promoted the yield formation in average by $14 \%$ higher versus untreated variants (control).

3) Complex of pre-sowing soil tillage with harrow and double treatment with herbicide ensured the yield capacity by $30 \%$ higher than the control variant (harrowing without herbicide treatment).

While maintaining these tendencies, it is concluded that the BDM-4 disk harrow is the optimal unit for pre-sowing soil tillage for oil flax sowings on sod-podzolic soils of the Middle Preduralie. Double treatment of sowings with the «Lontrel-300» herbicide is able to not only reduce the number of weed plants but also statistically increase the total yield capacity of oilseeds.

\section{References}

1. V.A. Zubtsov, L.L. Osipova, T.I. Lebedeva, Russian Chemical Journal, 2, 14 (2002)

2. V.N. Bobkov, Social status and standard of living of the population of Russia, C69 Stat.sb., Rosstat, 352 (2019)

3. A.N. Korzunova, Flax, 130 (2013)

4. V. Zhivetin, L.N. Ginzburg, Oil Flax and Its Integrative Use, 92 (2000)

5. S.C. Cunnane, S. Ganguli, C. Menard, A.C. Liede, M.J. Hamadeh, Z.Y. Chen, T.M.S. Wolever, British Journal of Nutrition, 69(2), 443 (1993)

6. D.E. Barre, K.A. Mizier-Barre, O. Griscti, K. Hafez, Journal of Oleo Science, 57(5), 269 (2008)

7. S. Khalesi, R. Jamaluddina, A. Ismailab, Int J Appl Sci Technol., 1(4), 84 (2011) 
8. B.A.Dospekhov, Field Experiment Technique (with the basics of statistical processing of research results), 6 ed., 352 (2011)

9. V.M. Lukomets, Prospective Resource-Saving Technology of Oil Flax Production: Methodological Guidelines, 52 (2010)

10. Flax, Great Soviet Encyclopedia, 3 ed (1969)

11. V.B. Belyak, V.N. Brazhnikov, O.F. Brazhnikova, Selection and Seed Production of Agricultural Crops, 278 (2003) 